\title{
MBL2 gene polymorphisms and susceptibility to tuberculosis in a northeastern Brazilian population
}

\author{
Heidi Lacerda Alves da Cruz ${ }^{\text {a }}$, Ronaldo Celerino da Silva ${ }^{\text {b,c }}$, Ludovica Segat ${ }^{\text {, }}$ \\ Márcia Schneider Zuzarte de Mendonça Gomes de Carvalho ${ }^{\mathrm{a}, \mathrm{b}}$, Lucas André Cavalcanti Brandão ${ }^{\mathrm{c}, \mathrm{e}}$, \\ Rafael Lima Guimarães ${ }^{\text {b,c }}$, Fabiana Cristina Fulco Santos ${ }^{a}$, Laís Ariane Siqueira de Lira ${ }^{\text {a }}$, \\ Lilian Maria Lapa Montenegro ${ }^{a}$, Haiana Charifker Schindler ${ }^{a}$, Sergio Crovella ${ }^{d, *}$
}

\footnotetext{
a Department of Immunology, Aggeu Magalhães Research Center-CPqAM/FIOCRUZ, Av. Prof. Moraes Rego, s/n', CEP 50.670-420 Recife, Pernambuco, Brazil

${ }^{\mathrm{b}}$ Department of Genetics, Federal University of Pernambuco, Av. Prof. Moraes Rego, s/n ${ }^{\circ}$, CEP 50.670-420 Recife, Pernambuco, Brazil

${ }^{\mathrm{c}}$ Laboratory of Immunopathology Keizo Asami, Federal University of Pernambuco, Av. Prof. Moraes Rego, s/n', CEP 50.670-420 Recife, Pernambuco, Brazil

'Institute for Maternal and Child Health- IRCCS "Burlo Garofolo"- Via dell'Istria 65/1, 34137 Trieste, Italy

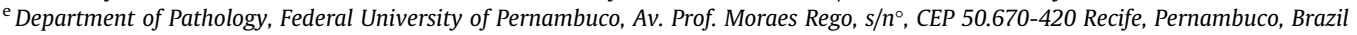

\section{A R T I C L E I N F O}

\section{Article history:}

Available online 21 March 2013

\section{Keywords:}

Tuberculosis

Innate immunity

MBL2

Pulmonary

Polymorphisms

\begin{abstract}
A B S T R A C T
The innate immune system represents the first line of host defense against pathogens. Genetics factors regulating the immune responses play a role in the susceptibility to infectious diseases, such as tuberculosis (TB). We analyzed MBL2 promoter and exon 1 functional single nucleotide polymorphisms (SNPs) in a group of 155 TB patients and 148 healthy controls in order to evaluate their influence on the onset of infection and TB development. There was no association between MBL2 -550 HL promoter polymorphisms and susceptibility to develop TB, but heterozygous - $221 \mathrm{Y} / \mathrm{X}$ genotype was significantly more frequent in pulmonary TB patients than controls. Moreover, MBL2 exon $1 \mathrm{O}$ allele, was significantly associated with susceptibility to TB development in general $(p=0.023$, OR $=1.61,95 \% \mathrm{CI} 1.05-2.49)$ and pulmonary TB $(p=0.0008, \mathrm{OR}=2.16,95 \% \mathrm{CI} 1.35-3.46)$; $\mathrm{C}$ allele at codon 57 , as well as A/C genotype, were significantly more frequent in TB patients than in controls. Our results indicate that MBL2 polymorphisms, especially at codon 57 , could be considered as risk factors for TB development.
\end{abstract}

(C) 2013 Elsevier B.V. All rights reserved.

\section{Introduction}

Among all the infectious diseases affecting humans, tuberculosis (TB) caused by Mycobacterium tuberculosis remains one of the most lethal (WHO, 2011). Based on tuberculin test, epidemiologists estimate that one-third of the world population (2.2 billion people) is infected with the bacillus (Ducati et al., 2006). In Brazil, 80,000 cases are registered annually with incidence rate of 37.1/1,00,000 inhabitants, according to data from the Brazilian Health Ministry (Brazil, 2008).

The risk of infected individuals to develop the active form of the disease during their lifetime ranges between $5 \%$ and $10 \%$. In these individuals, the chances of illness depend on the immune system's ability to prevent the multiplication of dormant $M$. tuberculosis (Oliveira et al., 2004).

Innate immunity is the first line of host defense. At some time in the cycle of TB infection, most infected humans, who are immunocompetent, will show the presence of the mycobacteria and begin

\footnotetext{
* Corresponding author. Tel.: +39 040 3785422; fax: +39 0403785540 .

E-mail address: crovelser@gmail.com (S. Crovella).
}

to generate an immune response, destroying macrophages containing bacilli. This process will result in the presentation of mycobacterial antigens to the host immune system, leading to the generation of a specific immune response against $M$. tuberculosis (Clark-Curtiss and Haydel, 2003; Ducati et al., 2006).

Previous studies have demonstrated the association of several genes with the susceptibility to TB, such as human leukocyte antigen $(H L A)$, natural resistance-associated macrophage protein 1 (NRAMP1), vitamin D receptor (VDR), interleukin-1 (IL1), interleukin-12B and interleukin-12 receptor (IL-12Rß1) (Singh et al., 1983; Bellamy et al., 1998, 1999; Goldfeld et al., 1998; Greenwood et al., 2000; Wilkinson et al., 2000; Remus et al., 2004; Morris et al., 2011). A linkage analysis on sib-pairs conducted in Africa (Bellamy et al., 2000) has mapped TB susceptibility loci at chromosomes 15q11-13 and Xq26, although another genome-wide scan, performed in the north of Brazil, did not replicate those findings (Miller et al., 2004).

Certain innate immunity proteins, such as the mannose binding lectin (MBL), can recognize the mannose on pathogens' surface, promoting both the opsonization and activation of the complement system. MBL deficiency has been associated with an 
increased frequency of various infections, including sepsis, aspergillosis, meningococcal disease and invasive pneumococcal infections.

In TB context, the role of MBL is controversial. Some studies showed that MBL deficiency protects against TB (Garcia-Laorden et al., 2006; Cosar et al., 2008; Denholm et al., 2010; Liu et al., 2010); on other hand, MBL deficiency was also associated with susceptibility to TB infection (Selvaraj et al., 2006; Alagarasu et al., 2007; Capparelli et al., 2009).

Mbl2 gene (10q11.2-q21) encodes for the mannose binding lectin and presents several polymorphisms, six of which are known for their functional effect. Three are located at exon 1: the first one, rs5030737 is a C>T transition at codons 52 (CGT>TGT) that results in Arg52Cys substitution (where the variant allele is also known as "D" allele), rs 1800450 is a G>A transition (known as "B" allele) at codons 54 (GGC>GAC) resulting in Gly54Asp substitution, and rs1800451 is a G>A transition (known as "C" allele) at codon 57 (GGA>GAA) resulting in Gly57Glu substitution. (Madsen et al., 1994), These SNPs together are identified as "AO" polymorphisms, were the " $A$ " wild-type allele, indicate no variant alleles at codons 52, 54 and 57 (C, G and G nucleotide respectively) and the "O" mutant allele, indicate the presence of one or more mutant alleles in either codons 52, 54 and 57 (T, A and A nucleotide, respectively). The presence of a $\mathrm{O}$ allele, in heterozygosis correlate with low levels of functional protein in the serum, and in homozygosis with almost undetectable MBL levels in both healthy individuals and patients affected by various diseases (Madsen et al., 1994; Wallis, 2003).

Mbl2 variants are quite frequent, although unevenly distributed in human populations (Garred et al., 2006; Thye et al., 2011). Allele " $\mathrm{B}$ " is extremely rare in West Africa but occurs at frequencies of 0.14 (Caucasians), 0.25 (Asians) and 0.50 (indigenous South Americans). On the other hand, the " $C$ " allele is rare among Caucasians but common in sub-Saharan Africa. The " $D$ " allele in general is rather uncommon and largely restricted to North Africans and Caucasians. The high frequencies of these alleles in certain populations suggested that functional MBL deficiencies might confer some biological advantage (Bernig et al., 2004).

In addition to exon 1 polymorphisms, there are three SNPs in $M B L 2$ gene promoter region, namely $-550 C>G$ (rs11003125, also known as "HL" variant, where $\mathrm{L}$ is the wild type allele), $-221 \mathrm{G}>\mathrm{C}$ (rs7096206, "XY" variant, where $\mathrm{Y}$ is the wild type allele) and +4C > T (rs7095891, "PQ" variant, where P is the wild type allele), that can influence transcription rate and consequently the concentration of serum MBL. SNPs in exon 1 are in strong linkage disequilibrium with the ones located at the promoter region, originating seven common haplotypes (HYPA, LYQA, LYPA, LXPA, LYPO, LYQO and HYPO) showing considerable variation in their frequencies among different ethnic groups (Steffensen et al., 2000).

This study aims to examine whether MBL2 gene polymorphisms are associated with the occurrence of active tuberculosis, in a Brazilian population from the state of Pernambuco, Northeast of Brazil, in order to evaluate their possible influence on disease onset.

\section{Material and methods}

\subsection{Study population}

The study population comprises 155 patients (101 males and 54 females, mean age $29.83 \pm 16.14$ ) from the "Hospital das Clínicas Universidade Federal de Pernambuco" (HC-UFPE), "Instituto de Medicina Integral Professor Fernando Figueira" (IMIP), "Hospital Barão de Lucena" (HBL/SUS) and "Hospital Otávio de Freitas" (HOF/SUS), all located at metropolitan area of Recife, Pernambuco, Brazil.
This group was composed of 119 pulmonary TB (84 males and 35 females, mean age 28 years \pm 10.4 ) and 36 extra-pulmonary tuberculosis patients (17 males and 19 females. mean age 31 years \pm 16.9 ). The diagnosis was based on clinical symptoms and radiographic findings, along with bacteriological confirmation (culture, smear and/or polymerase chain reaction) as described by the American Thoracic Society (2000).

As control group, we enrolled 148 healthy individuals ( $81 \mathrm{fe}-$ males, 67 males; mean age 25 years \pm 2.42 ), unrelated to patients, with negative Mantoux test, showing no symptoms of tuberculosis or previous history of the disease. All patients and control subjects were matched for ethnicity, HIV-negative and not under immunosuppressive medication. We tried to choose the best controls in terms of similarity of exposition to TB patients, by enrolling healthy individuals from the same areas (metropolitan Recife, Pernambuco, Brazil), where patients have been collected. HIV infection was exclusion criteria when enrolling TB patients, since MBL2 polymorphisms, being also related with susceptibility to HIV infection, could represent a confounding factor.

Written and informed consent was obtained form the patients or their parents (in case of minor age) and the CPqAM/FIOCRUZ Ethics Committee (CEP Registration - 55/05) approved the study. Patients underwent a standardized clinical-epidemiological questionnaire. Data were stored and subsequently processed using the Statistical Package for Social Sciences (SPSS - version 10.0 for Windows).

\subsection{MBL2 genotyping}

Genomic DNA was extracted from whole blood using QIAamp DNA Blood Kit, according to manufacturer instructions (QIAamp DNA Blood Midi Kit, Qiagen).

Mbl2 promoter and exon 1 polymorphisms (GenBank accession: rs11003125, rs7096206, rs5030737, rs1800450, rs1800451) have been genotyped by direct sequencing with the following primers: 5'-GCCAGTGGTTTTTGACTCAC-3' and 3'-CCTCATATCCCCAGGCAGT5', using the Big Dye Terminator kit 3.1 (Applied Biosystems). Sequencing reactions were run on the ABI 3130 genetic Analyzer (Applied Biosystems, Foster City, CA, USA); sequences were handled using the 4Peaks (http://mekentosj.com/4peaks/) and Codon-Code Aligner (http://www.codoncode.com/aligner/) software.

The haplotypes and combined genotypes were computed using Arlequin version 3.01 software (available at http://cmpg.unibe.ch/ software/arlequin3/) and identified by a specific nomenclature, where the first two letters indicate the variants of the promoter region ("HL" and "XY" variants) and the third letter indicates the combination for the three polymorphisms in exon 1 ("AO" variant) (Garred et al., 1997). The SNP at position +4 has been genotyped but not considered in this study because of very low relevance in the variation of serum MBL levels. (Bouwman et al., 2006)

\subsection{Statistical analysis}

Chi-square test was used to verify the Hardy-Weinberg equilibrium and the Fisher's exact test was performed for pair-wise comparison of allele, genotype and haplotype frequencies using contingency tables as appropriate, and only $p$ values $<0.05$ were considered as significant. All the statistical analyses were carried out using the open-source R package, (R Development Core Team, 2012) available at http://www.r-project.org site. When calculating odds ratio (OR) in Tables 1 and 2, the alleles and corresponding homozygous genotypes with major frequency in the control group have been selected as reference $(\mathrm{OR}=1)$ and the other ORs have been presented relative to that reference (Fisher's exact test, $2 \times 2$ contingency tables, degrees of freedom $=1$ ) 
Table 1

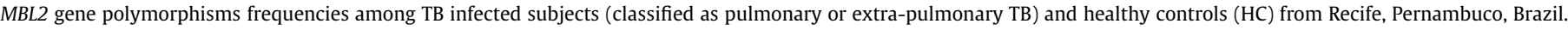

\begin{tabular}{|c|c|c|c|c|c|c|c|}
\hline & \multicolumn{3}{|l|}{ TB patients } & \multirow{2}{*}{$\begin{array}{l}\text { Healthy controls } \\
n=148\end{array}$} & \multicolumn{3}{|l|}{ p-Value; OR [95\%C.I.] } \\
\hline & $\begin{array}{l}\text { Total } \\
n=155\end{array}$ & $\begin{array}{l}\text { Pulmonary } \\
n=119\end{array}$ & $\begin{array}{l}\text { Extra-pulmonary } \\
n=36\end{array}$ & & Total vs. HC & Pulmonary vs. HC & $\begin{array}{l}\text { Extra-pulmonary } \\
\text { vs. HC }\end{array}$ \\
\hline \multicolumn{8}{|c|}{ Promoter "HL" variant } \\
\hline \multicolumn{8}{|l|}{ Alleles } \\
\hline $\mathrm{H}$ & $83(0.27)$ & $61(0.26)$ & $22(0.30)$ & $99(0.33)$ & Ref & Ref & Ref \\
\hline $\mathrm{L}$ & $227(0.73)$ & $177(0.74)$ & $50(0.70)$ & $197(0.67)$ & $0.076 ; 1.37$ [0.95-1.97] & $0.057 ; 1.45$ [0.98-2.17] & $0.677 ; 1.14$ [0.63-2.09] \\
\hline \multicolumn{8}{|l|}{ Genotypes } \\
\hline $\mathrm{H} / \mathrm{H}$ & $10(0.06)$ & $8(0.07)$ & $2(0.06)$ & $19(0.13)$ & Ref & Ref & Ref \\
\hline $\mathrm{H} / \mathrm{L}$ & $63(0.41)$ & $45(0.38)$ & $18(0.50)$ & $61(0.41)$ & $0.148 ; 1.95[0.78-5.10]$ & $0.274 ; 1.74[0.65-5.0]$ & $0.230 ; 2.77$ [0.57-26.8] \\
\hline $\mathrm{L} / \mathrm{L}$ & $82(0.53)$ & $66(0.55)$ & $16(0.44)$ & $68(0.46)$ & $0.068 ; 2.28[0.93-5.88]$ & $0.089 ; 2.29[0.88-6.49]$ & $0.517 ; 2.22[0.45-21.6]$ \\
\hline $\mathrm{H} / \mathrm{L}+\mathrm{L} / \mathrm{L}$ & $145(0.94)$ & $111(0.93)$ & $34(0.94)$ & $129(0.87)$ & $0.077 ; 2.13[0.90-5.32]$ & $0.107 ; 2.03$ [0.83-5.60] & $0.378 ; 2.49[0.55-23.1]$ \\
\hline \multicolumn{8}{|c|}{ Promoter "XY" variant } \\
\hline $\mathrm{Y}$ & $251(0.81)$ & $190(0.80)$ & $61(0.85)$ & $252(0.85)$ & Ref & Ref & Ref \\
\hline $\mathrm{X}$ & $59(0.19)$ & $48(0.20)$ & $11(0.15)$ & $44(0.15)$ & $0.194 ; 1.34$ [0.85-2.11] & $0.108 ; 1.44$ [0.89-2.33] & $1 ; 1.03$ [0.45-2.18] \\
\hline \multicolumn{8}{|l|}{ Genotypes } \\
\hline $\mathrm{Y} / \mathrm{Y}$ & $101(0.65)$ & $75(0.63)$ & $26(0.72)$ & $110(0.74)$ & Ref & Ref & Ref \\
\hline $\mathrm{Y} / \mathrm{X}$ & $49(0.32)$ & $40(0.34)$ & $9(0.25)$ & $32(0.22)$ & $0.069 ; 1.66[0.96-2.91]$ & $0.036^{\mathrm{a}} ; 1.82[1.02-3.30]$ & $0.661 ; 1.18$ [0.44-2.95] \\
\hline $\mathrm{X} / \mathrm{X}$ & $5(0.03)$ & $4(0.03)$ & $1(0.03)$ & $6(0.04)$ & $1 ; 0.908[0.21-3.69]$ & $1 ; 0.977[0.19-4.28]$ & $1 ; 0.706[0.01-6.22]$ \\
\hline $\mathrm{Y} / \mathrm{X}+\mathrm{X} / \mathrm{X}$ & $54(0.35)$ & $44(0.37)$ & $10(0.28)$ & $38(0.26)$ & $0.104 ; 1.54[0.91-2.68]$ & $0.061 ; 1.69[0.97-2.96]$ & $0.833 ; 1.11[0.43-2.66]$ \\
\hline \multicolumn{8}{|c|}{ Exon 1 "AO" variant } \\
\hline A & $239(0.77)$ & $138(0.77)$ & $56(0.78)$ & $250(0.84)$ & Ref & Ref & Ref \\
\hline $\mathrm{O}$ & $71(0.23)$ & $55(0.23)$ & $16(0.22)$ & $46(0.16)$ & $0.023^{\mathrm{a}} ; 1.61$ [1.05-2.49] & $0.00085^{\mathrm{a}} ; 2.16[1.35-3.46]$ & $0.217 ; 1.55$ [0.76-3.03] \\
\hline \multicolumn{8}{|l|}{ Genotypes } \\
\hline $\mathrm{A} / \mathrm{A}$ & $92(0.60)$ & $71(0.60)$ & $21(0.58)$ & $108(0.73)$ & Ref & Ref & Ref \\
\hline $\mathrm{A} / \mathrm{O}$ & $55(0.35)$ & $41(0.34)$ & $14(0.40)$ & $34(0.23)$ & $0.015^{\mathrm{a}} ; 1.89$ [1.10-3.27] & $0.037^{\mathrm{a}} ; 1.82$ [1.02-3.28] & $0.087 ; 2.11[0.88-4.90]$ \\
\hline $0 / 0$ & $8(0.05)$ & $7(0.06)$ & $1(0.02)$ & $6(0.04)$ & $0.581 ; 1.56$ [0.45-5.67] & $0.384 ; 1.76[0.48-6.65]$ & $1 ; 0.858[0.01-7.66]$ \\
\hline $\mathrm{A} / \mathrm{O}+\mathrm{O} / \mathrm{O}$ & $63(0.40)$ & $48(0.40)$ & $15(0.42)$ & $40(0.27)$ & $0.029^{\mathrm{a}} ; 1.73$ [1.04-2.89] & $0.025^{\mathrm{a}} ; 1.82[1.05-3.15]$ & $0.104 ; 1.92[0.83-4.35]$ \\
\hline
\end{tabular}

$\mathrm{OR}=$ odds ratio; C.I. = confidence intervals; Ref = reference.

a Statistically significant p-values.

The power analysis was performed with the "G*power" software (version 3.0.5, http://www.psycho.uni-duesseldorf.de/ abteilungen/aap/gpower3/), post hoc goodness of fit $\chi^{2}$ test, with an "-error" probability of 0.05 .

The possible presence of population stratification bias has been gauged according to Lee and Wang (2008), considering MBL2 SNP frequencies at codon 57 reported by Boldt et al. (2006) for different Brazilian populations, and incidence rates of TB in Brazil, as reported by Hijjar et al., 2001.

\section{Results}

The results of MBL2 promoter region and exon 1 genotyping in TB patients and controls are shown in Table 1. All polymorphisms were in Hardy-Weinberg equilibrium in both patients and control groups.

MBL2 promoter "HL" SNP showed no difference in allelic or genotype frequencies between TB patients globally considered and healthy controls, as well as between each of the two TB subgroups (pulmonary and extra-pulmonary) and controls.

For the promoter "XY" variant, although no differences were seen in allelic frequencies, the $\mathrm{Y} / \mathrm{X}$ heterozygous genotype was significantly more frequent in pulmonary TB patients than controls, and associated with increased susceptibility to TB development $(p=0.036 ;$ OR $=1.82 ; 95 \% \mathrm{CI}=1.02-3.30)$.

When MBL2 exon 1 "AO" variants were analyzed, the $O$ allele was significantly more frequent in TB patients in general (23\%) than in healthy controls (16\%), and associated with increased susceptibility to TB development ( $p=0.023$, OR $=1.61,95 \%$ CI $1.05-$ 2.49 ). Also the $\mathrm{A} / \mathrm{O}$ genotype was more frequent in TB patients than in healthy controls when considered alone (35\% vs. $23 \%, p=0.015$, $\mathrm{OR}=1.89,95 \% \mathrm{CI} 1.10-3.27)$ or in combination with the $\mathrm{O} / \mathrm{O}$ geno- type $(\mathrm{A} / \mathrm{O}$ plus $\mathrm{O} / \mathrm{O} p=0.029, \mathrm{OR}=1.73,95 \% \mathrm{CI} 1.04-2.89)$, indicating an association with susceptibility to TB development.

When the specific form of TB was considered, we found that the $\mathrm{O}$ allele, $\mathrm{A} / \mathrm{O}$ and $\mathrm{A} / \mathrm{O}$ plus $\mathrm{O} / \mathrm{O}$ genotypes were all significantly more frequent in pulmonary (but not in extra-pulmonary) TB patients than in controls.

In addition to analyzing the exon 1 polymorphisms at codon 52 , 54 and 57 together as $\mathrm{O}$ alleles, we then considered the three polymorphisms singularly (B-D variant alleles, Table 2 ). No significant differences were found when we compared the frequencies of polymorphisms at codons 52 ("AD" variant) and 54 ("AB" variant) between TB patients and controls, as well as between pulmonary and extra-pulmonary TB and controls. The analysis of codon 57 showed that the mutant $C$ allele and the $A / C$ genotype were significantly more frequent in TB patients than controls and both associated with an increased risk of $\mathrm{TB}$; the same association was observed in pulmonary TB patients but not in extra-pulmonary. The $\mathrm{C} / \mathrm{C}$ mutant genotype was never found in any of the $155 \mathrm{pa}-$ tients, and any of the controls (Table 2).

In order to exclude that the association of the $57 \mathrm{C}$ allele might be due to the confounding effect of a population stratification bias, we evaluated the potential bias in our study, according to the method described by Lee and Wang (2008). Considering an incidence rate of TB in the Brazilian population variable between 30/ 1,00,000 and 92/1,00,000 (Hijjar et al., 2001) and an allelic frequency of codon 57 for the Brazilians ranging from 0.003 to 0.24 , as reported by Boldt et al. (2006), the potential confounding rate ratio $(\mathrm{U})$ was 2.49 , which is less than the OR we found for the codon 57 SNP $(O R=2.74)$. This indicates that the association found between MBL2 codon 57 SNP and TB cannot be ascribable to population stratification bias alone.

We also considered the MBL2 combined promoter and exon 1 genotypes, classified according to Bouwman et al. (2006) as high 
Table 2

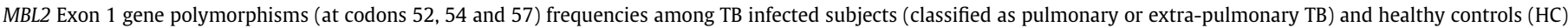
from Recife, Pernambuco, Brazil.

\begin{tabular}{|c|c|c|c|c|c|c|c|}
\hline & \multicolumn{3}{|l|}{ TB patients } & \multirow{2}{*}{$\begin{array}{l}\text { Healthy controls } \\
n=148\end{array}$} & \multicolumn{3}{|l|}{ p-Value; OR [95\%C.I.] } \\
\hline & $\begin{array}{l}\text { Total } \\
n=155\end{array}$ & $\begin{array}{l}\text { Pulmonary } \\
n=119\end{array}$ & $\begin{array}{l}\text { Extra-pulmonary } \\
n=36\end{array}$ & & Total vs. HC & Pulmonary vs. HC & $\begin{array}{l}\text { Extra-pulmonary } \\
\text { vs. HC }\end{array}$ \\
\hline \multicolumn{8}{|c|}{ Codon 52 "AD" variant } \\
\hline \multicolumn{8}{|c|}{ Alleles } \\
\hline A & $296(0.95)$ & $226(0.95)$ & $70(0.97)$ & $285(0.96)$ & Ref & Ref & Ref \\
\hline $\mathrm{D}$ & $14(0.05)$ & $12(0.05)$ & $2(0.03)$ & $11(0.04)$ & $0.685 ; 1.22[0.50-3.03]$ & $0.522 ; 1.37[0.54-3.50]$ & $1 ; 0.74[0.07-3.51]$ \\
\hline \multicolumn{8}{|l|}{ Genotypes } \\
\hline $\mathrm{A} / \mathrm{A}$ & $142(0.91)$ & $108(0.91)$ & $34(0.94)$ & $138(0.93)$ & Ref & Ref & Ref \\
\hline $\mathrm{A} / \mathrm{D}$ & $12(0.08)$ & $10(0.08)$ & $2(0.06)$ & $9(0.06)$ & $0.653 ; 1.29[0.48-3.59]$ & $0.482 ; 1.41$ [0.49-4.09] & $1 ; 0.902$ [0.09-4.65] \\
\hline $\mathrm{D} / \mathrm{D}$ & $1(0.01)$ & $1(0.01)$ & $0(0)$ & $1(0.01)$ & $1 ; 0.971[0.01-76.78]$ & $1 ; 1.27 ;[0.01-100.9]$ & $1 ; 0[0.0-159.4]$ \\
\hline $\mathrm{A} / \mathrm{D}+\mathrm{D} / \mathrm{D}$ & $13(0.09)$ & $11(0.09)$ & $2(0.06)$ & $10(0.07)$ & $0.667 ; 1.26$ [0.49-3.33] & $0.498 ; 1.40[0.51-3.83]$ & $1 ; 0.812$ [0.08-4.07] \\
\hline \multicolumn{8}{|c|}{ Codon 54 " $A B$ " variant } \\
\hline A & $275(0.89)$ & $212(0.90)$ & $63(0.88)$ & $269(0.91)$ & Ref & Ref & Ref \\
\hline B & $35(0.11)$ & $26(0.10)$ & $9(0.12)$ & $27(0.09)$ & $0.422 ; 1.26[0.72-2.24]$ & $0.560 ; 1.22[0.66-2.24]$ & $0.380 ; 1.42[0.55-3.30]$ \\
\hline \multicolumn{8}{|l|}{ Genotypes } \\
\hline $\mathrm{A} / \mathrm{A}$ & $122(0.79)$ & $95(0.80)$ & $27(0.75)$ & $124(0.84)$ & Ref & Ref & Ref \\
\hline $\mathrm{A} / \mathrm{B}$ & $31(0.20)$ & $22(0.18)$ & $9(0.25)$ & $21(0.14)$ & $0.226 ; 1.49[0.78-2.90]$ & $0.402 ; 1.36[0.67-2.78]$ & $0.138 ; 1.95[0.70-5.08]$ \\
\hline $\mathrm{B} / \mathrm{B}$ & $2(0.01)$ & $2(0.02)$ & $0(0)$ & $3(0.02)$ & $1 ; 0.678$ [0.05-6.03] & $1 ; 0.870[0.07-7.75]$ & $1 ; 0[0.0-11.57]$ \\
\hline $\mathrm{A} / \mathrm{B}+\mathrm{B} / \mathrm{B}$ & $33(0.21)$ & $24(0.20)$ & $9(0.25)$ & $24(0.16)$ & $0.303 ; 1.39[0.75-2.62]$ & $0.426 ; 1.30[0.66-2.56]$ & $0.230 ; 1.71[0.62-4.37]$ \\
\hline \multicolumn{8}{|c|}{$\begin{array}{l}\text { Codon } 57 \text { "AC" variant } \\
\text { Alleles }\end{array}$} \\
\hline A & $288(0.93)$ & $221(0.93)$ & $67(0.93)$ & $288(0.97)$ & Ref & Ref & Ref \\
\hline $\mathrm{C}$ & $22(0.07)$ & $17(0.07)$ & $5(0.07)$ & $8(0.03)$ & $0.014^{\mathrm{a}} ; 2.74[1.15-7.25]$ & $0.021^{\mathrm{a}} ; 2.76[1.10-7.54]$ & $0.144 ; 2.67$ [0.66-9.62] \\
\hline \multicolumn{8}{|l|}{ Genotypes } \\
\hline $\mathrm{A} / \mathrm{A}$ & $133(0.86)$ & $102(0.93)$ & $31(0.86)$ & $140(0.95)$ & Ref & Ref & Ref \\
\hline $\mathrm{A} / \mathrm{C}$ & $22(0.14)$ & $17(0.07)$ & $5(0.14)$ & $8(0.05)$ & $0.012^{\mathrm{a}} ; 2.88[1.18-7.76]$ & $0.018^{\mathrm{a}} ; 2.90[1.13-8.09]$ & $0.137 ; 2.800 .67-10.51$ \\
\hline $\mathrm{C} / \mathrm{C}$ & $0(0)$ & $0(0)$ & $0(0)$ & $0(0.00)$ & $1 ; 0[0.0-$-Inf $]$ & $1 ; 0[0.0-$-Inf $]$ & $1 ; 0[0.0-$ Inf $]$ \\
\hline $\mathrm{A} / \mathrm{C}+\mathrm{C} / \mathrm{C}$ & $22(0.14)$ & $17(0.07)$ & $5(0.14)$ & $8(0.05)$ & $0.012^{\mathrm{a}} ; 2.88[1.18-7.76]$ & $0.018^{\mathrm{a}} ; 2.90[1.13-8.09]$ & $0.137 ; 2.800 .67-10.51$ \\
\hline
\end{tabular}

$\mathrm{OR}=$ odds ratio; C.I. = confidence intervals; Ref = reference

a Statistically significant $p$-values.

producers (HYA/HYA, HYA/LYA, HYA/LXA, LYA/LYA, and LYA/LXA), low producers (LXA/LXA, HYA/O, and LYA/O), and deficient producers (LXA/O and $\mathrm{O} / \mathrm{O}$ ) (Table 3): no statistical differences in the frequencies were observed between the analyzed groups.

Finally, we calculated the statistical power: our study has a power $>95 \%$ (with $5 \%$ confidence) to detect a medium or large effect size ( $w=0.3$ or $w=0.05)$ for $M B L 2$ genotypes in overall or pulmonary/extrapulmonary TB susceptibility. Assuming a lower effect size $(\mathrm{w}<0.2$ or $\mathrm{w}<0.1)$, the power decreases $(<80 \%$ and $<30 \%$, respectively) indicating that the present study may have failed, due to a type II error to detect small effects (i.e. false negative).

\section{Discussion}

Host genetic factors can determine differences in the susceptibility and/or resistance to infections, as well as in the clinical patterns of diseases. In our study we showed that MBL2 "XY" promoter polymorphism and the "AC" polymorphism at codon 57 are involved in the susceptibility to TB development in a northeastern Brazilian population. A significant association was found for $M B L 2 C$ allele and $\mathrm{A} / \mathrm{C}$ genotype at codon 57 , and for the $\mathrm{Y} / \mathrm{X}$ promoter genotype, with the pulmonary but not extrapulmonary form of TB disease.

So, we can assume that there is no association between the presence of these variations and the development of extra-pulmonary TB and that MBL2 variant can influence the risk only of the pulmonary form; however, since MBL2 frequencies were not significantly different between pulmonary and extra-pulmonary TB patients, the lack of association in the extra-pulmonary group could be due to the small sample size of this group (36 patients). Calculations of statistical power indicate that our study, although having a power $>95 \%$ to detect a medium/large effect of $M B L 2$ variants in TB, may have instead failed to detect a smaller effect (power $<30 \%$ for $\mathrm{w}=0.01$ ).

Mbl2 polymorphisms have been associated with low levels of MBL in serum. Individuals homozygous for MBL2 mutation have almost undetectable levels of MBL $(\leqslant 10 \mathrm{ng} / \mathrm{ml}$ ); average levels are reduced to approximately $350 \mathrm{ng} / \mathrm{ml}$ in heterozygotes, while MBL concentration reaches over $1600 \mathrm{ng} / \mathrm{ml}$ in wild type homozygous individuals (Davies et al., 2001). The decrease in concentration of circulating MBL has been associated with recurrent infections in childhood and possibly in adults. However, the effect of low MBL levels on TB has been controversial: some studies reported low MBL levels as associated with protection against the disease, whereas others estimated a relation with increased susceptibility (Denholm et al., 2010).

Alagarasu et al. (2007) and Selvaraj et al. (2006), have previously suggested that $\mathrm{O} / \mathrm{O}$ genotype may be associated with susceptibility to $\mathrm{TB}$, since they observed a significant increase in the frequency of $\mathrm{O} / \mathrm{O}$ genotype in $\mathrm{TB}$ patients than controls. Additionally, Capparelli et al. (2009), reported higher frequencies of the $\mathrm{O} / \mathrm{O}$ genotype among patients ( $22.3 \%$ vs. $3.5 \%$ in controls) in an Italian population. In our study, the $\mathrm{O} / \mathrm{O}$ genotype frequency distribution was similar between patients and controls, but the $O$ allele, as well as the $\mathrm{A} / \mathrm{O}$ genotype, were significantly more frequent in TB patients, (pulmonary TB), than healthy controls; the homozygous $\mathrm{A} /$ A genotype, responsible for higher levels of circulating MBL proteins, was more frequent in controls than in TB patients. These data indicate a possible protective effect of medium/high levels of MBL toward TB infection.

On other hand, some studies have shown that MBL deficiency protects against disease caused by $M$. tuberculosis (Garcia-Laorden et al., 2006; Cosar et al., 2008; Denholm et al., 2010; Liu et al., 
Table 3

MBL2 combined genotypes frequencied in TB infected subjects (classified as pulmonary or extrapulmonary TB) and healthy controls (HC) from Recife, Pernambuco, Brazil.

\begin{tabular}{|c|c|c|c|c|c|c|c|}
\hline \multirow[t]{2}{*}{ MBL2 combined genotypes } & \multicolumn{3}{|c|}{ TB Patients } & \multirow{2}{*}{$\begin{array}{l}\text { Healthy controls } \\
n=148\end{array}$} & \multicolumn{3}{|l|}{ p-Value; OR [95\% C.I.] } \\
\hline & $\begin{array}{l}\text { Total } \\
n=155\end{array}$ & $\begin{array}{l}\text { Pulmonary } \\
n=119\end{array}$ & $\begin{array}{l}\text { Extra-pulmonary } \\
n=36\end{array}$ & & Total vs. HC & Pulmonary vs. HC & $\begin{array}{l}\text { Extra-pulmonary } \\
\text { vs. HC }\end{array}$ \\
\hline $\begin{array}{l}\text { High production }(\mathrm{HP}) \\
\text { HYA/HYA } \\
\text { HYA/LYA } \\
\text { HYA/LXA } \\
\text { LYA/LYA } \\
\text { LYA/LXA }\end{array}$ & $88(0.57)$ & $67(0.56)$ & $21(0.58)$ & $92(0.62)$ & Ref & Ref & Ref \\
\hline $\begin{array}{l}\text { Low production }(L P) \\
\text { LXA/LXA }\end{array}$ & & & & & & & \\
\hline $\begin{array}{l}\text { HYA/O } \\
\text { LYA/O }\end{array}$ & $58(0.37)$ & $45(0.38)$ & $13(0.36)$ & $44(0.30)$ & $0.216 ; 1.37[0.82-2.31]$ & $0.231 ; 1.40[0.80-2.44]$ & $0.545 ; 1.29$ [0.54-2.99] \\
\hline $\begin{array}{l}\text { Deficient production (DP) } \\
\text { LXA/O } \\
\quad \mathrm{O} / \mathrm{O}\end{array}$ & $9(0.06)$ & $7(0.06)$ & $2(0.06)$ & $12(0.08)$ & $0.650 ; 0.785[0.27-2.14]$ & $0.806 ; 0.801[0.25-2.34]$ & $1 ; 0.73[0.07-3.68]$ \\
\hline
\end{tabular}

$\mathrm{OR}=$ odds ratio; C.I. = confidence intervals; Ref = reference.

2010). MBL2 variants, either structural alleles (codons 54 e 57) in Gambian children (Bellamy et al., 1998) and South African adults (Hoal-Van Helden et al., 1999), or full promoter haplotypes responsible for low MBL production, have been shown to be protective against tuberculosis. Søborg et al. (2003) demonstrated a significantly decreased frequency of individuals with the low-expressing MBL genotype in Caucasian patients compared to control subjects. The same tendency was also observed in patients of other ethnic origin. The authors hypothesized that heterozygosity for MBL2 variant alleles, responsible for low serum MBL levels, was associated with protection against clinical TB. Studies in Danish patients (Søborg et al., 2003) and Turkish children (Solğun et al., 2011) showed no association between MBL2 polymorphisms at the codons 54 and 57 and susceptibility to pediatric TB.

There is no doubt about the difficulty in comparing results from studies conducted in different populations, even when the same allele or haplotype are analyzed and the same study design is used. In addition to this, several studies investigated the role of MBL in TB in the context of HIV co-infection and thus with the confounding aspect of immunosuppression. As reported in the methods section we decided to eliminate this bias excluding patients with HIV co-infection form our study. Since the frequency of MBL2 polymorphism, as well as the incidence rates of tuberculosis, are know to vary among different populations, it is not excluded that some of the discrepant findings could be due, at least in part, to the different ethnicity of the subjects involved. The gene pool can greatly affect the results of an association study (El Sahly et al., 2004), so that investigations in homogeneous populations are preferred. In northeastern Brazilian population, African, Caucasian and Native American genetic contributions may have resulted in a different distribution of $M B L 2$ polymorphisms when compared with other populations.

In a recent study, Araújo et al. (2012) have studied the "AO" MBL2 variant in TB patients (pulmonary and extra-pulmonary) and healthy controls in a population from the Amazon region (Northern of Brazil), without finding any evidence of association between this polymorphism and TB. Despite both populations (our from Recife and the one from Belém do Pará studied by Araújo et al. (2012)) are from Brazil, there are considerable differences in their ethnic composition. Alves-Silva et al. (2000) had shown, by studying the mitochondrial genome of different regions of Brazil, that the Northern population (Belém do Pará) is a combined mixture of the genome of Native Americans (54\%), Africans (15\%) and Europeans (31\%), while the Northeastern population is comprised of 22\% Native American, 44\% African and 34\% European gen- omes. The fact that MBL2 "AO" polymorphism frequencies are significantly different between the controls in our study and those of Araújo et al., confirm the different ethnicity of the two groups considered in the two studies.

When considering a heterogeneous population such as the Brazilian one, population stratification represents a possible bias that should be taken into account. Nonetheless, we don't think that our results, evidencing an association of MBL2 codon 57 with tubercuolosis could be due exclusively to a type I error (i.e. false positive), for several reasons. Firstly, as indicated by Wacholder et al. (2000), population stratification bias will decrease as the number of ethnic strata increases; the Northeast Brazilian population (Recife) analyzed in this study, comprised at least three strata, Europeans, Africans, and Native Americans (from different tribes, increasing even more the number of strata). Moreover, as shown by both Khlat et al. (2004) and Pritchard and Donnelly (2001), the extent of bias caused by population stratification increases as the samples size becomes larger, due to the greater power to detect both real association and spurious ones. Once again, this is not the case with our study, since the number of samples analyzed (155 cases and 148 controls) can be considered of moderate size. Finally, by using in our study the formula described by Lee and Wang (2008) in order to gauge the potential impact of population stratification bias, we evidenced that the estimated potential bias $(U=2.49)$ was, although slightly, below the estimated OR for MBL2 codon 57 polymorphism, thus suggesting that our findings cannot be explained by the population stratification bias alone.

It is also worth to consider that TB is a multifactorial disease and its susceptibility depends not only upon host genetic aspects, but also on mycobacteria characteristics and on interactions with environmental factors. In a work, performed on Ghanaian patients, Thye et al. (2011) found that MBL2 low-producer haplotype LYQC (including the structural $C$ variant at codon 57) was associated, in a recessive mode of inheritance, with protection from TB caused by Mycobacterium africanum/Mycobacterium bovis but not from TB caused by $M$. tuberculosis. Moreover, all M. africanum isolates tested in their study bound recombinant human MBL to a greater extent than did M. tuberculosis isolates. The authors thus suggest that binding of MBL to mycobacteria may mediate phagocytosis by their target cell, the macrophage, and thus a decreased concentration and a functional impairment of MBL caused by mutations of the LYQC haplotype might reduce phagocytosis of mycobacteria by macrophages; a reduced uptake by macrophages could be one of the events that contribute to resistance against TB. However, this last observation was made in a mouse model that, as the 
authors admit, is not directly valid in human disease. Thye et al. findings are in contrast with our results, indicating association of MBL2 SNP at codon 57 with TB susceptibility. Once again, allele C frequencies are quite different between our population and Ghanaian, and moreover we don't exactly know to what extent our patients were infected by $M$. africanum or $M$. tuberculosis isolates. The putative protective MBL2 haplotype LYQC, which is virtually unique to sub-Saharan Africa and occurs there at high frequencies, might have been selected because it confers protection from clinical TB caused by M. africanum/M. bovis. The pattern of variation in the gene may represent a past adaptation to pathogens, with selection maintaining polymorphisms that optimized the fitness of the carriers in these environments. Widespread and ancient diseases such as tuberculosis, were found to be negatively associated with the MBL2 "low-secretor haplotypes" and protection against these diseases has been taken as evidence for the hypothesis that natural selection drove these MBL2 haplotypes to their actual high frequency. It is possible, as suggested by Boldt et al. (2006) that stochastic evolutionary factors erased much of the ancient imprint left by natural selection for $M B L 2$ on the regional scale, for example in Amerindian populations.

We also have to acknowledge that most of the significant $p$-values presented in our study are slightly within the statistically significant threshold and after application of Bonferroni's correction for multiple tests, the statistical significance will be lost. However, it is known that applying standard methods of correction for multiple tests, such as Bonferroni's adjustment can be very conservative and may be too stringent, probably not recognizing the small single effect such as those expected for a single gene in complex diseases. For this reason, we preferred to avoid setting rigorous limits in order to highlight the possible association between MBL2 and TB, an association that will have to be further investigated and confirmed by other studies as well as in different populations.

All this considered, although our study suggests that MBL2 polymorphisms may be associated with susceptibility to pulmonary TB development in Brazilian, further investigation and replica studies are needed in order to disclose MBL role in tuberculosis.

\section{Acknowledgments}

The authors thank all the health professionals from the Hospitals involved in the study that collaborated with the research. We thank the Laboratory of Immunoepidemiology - CPqAM/FIOCRUZ, the Laboratory of Immunopathology Keizo Asami, the Department of Genetics, Federal University of Pernambuco, the Graduate Program in Genetics for supporting physical and scientific, as well as FACEPE and CNPq, for financial support.

\section{References}

Alagarasu, K., Selvaraj, P., Swaminathan, S., Raghavan, S., Narendran, G., Narayanan, P.R., 2007. Mannose binding lectin gene variants and susceptibility to tuberculosis in HIV-1 infected patients of South India. Tuberculosis 6, 535-543.

Alves-Silva, J., da Silva Santos, M., Guimarães, P.E., Ferreira, A.C., Bandelt, H.J., Pena, S.D., Prado, V.F., 2000. The ancestry of Brazilian mtDNA lineages. Am. J. Hum. Genet. 67, 444-461.

American Thoracic Society, 2000. Diagnostic standards and classification of tuberculosis in adults and children. Am. J. Respir. Crit. Care. Med. 161, 13761395.

Araújo, M.S., Graça, E.S., Azevedo, V.N., Cayres-Vallinoto, I., Machado, L.F.A., Ishak, M.O.G., Ishak, R., Vallinoto, A.C.R., 2012. No evidence of association between MBL2 A/O polymorphisms and Mycobacterium tuberculosis infection in populations from the Brazilian Amazon region. Hum. Immunol. (Sep 19) pii: S0198-8859(12)00552-6.

Bellamy, R., Ruwende, C., Corrah, T., McAdam, K.P., Whittle, H.C., Hill, A.V., 1998. Variations in the NRAMP1 gene and susceptibility to tuberculosis in West Africans. N. Engl. J. Med. 338, 640-644.

Bellamy, R., Ruwende, C., Corrah, T., McAdam, K.P., Thursz, M., Whittle, H.C., Hill, A.V., 1999. Tuberculosis and chronic hepatitis B virus infection in Africans and variation in the vitamin D receptor gene. J. Infect. Dis. 179, 721-724.
Bellamy, R., Beyers, N., McAdam, K.P., Ruwende, C., Gie, R., Samaai, P., Bester, D. Meyer, M., Corrah, T., Collin, M., Camidge, D.R., Wilkinson, D., Hoal-Van Helden, E., Whittle, H.C., Amos, W., van Helden, P., Hill, A.V., 2000. Genetic susceptibility to tuberculosis in Africans: a genome-wide scan. Proc. Natl. Acad. Sci. 97, 80058009 .

Bernig, T., Taylor, J.G., Foster, C.B., Staats, B., Yeager, M., Chanock, S.J., 2004. Sequence analysis of the mannose-binding lectin (MBL2) gene reveals a high degree of heterozygosity with evidence of selection. Genes Immun. 5, 461-476.

Boldt, A.B., Culpi, L., Tsuneto, L.T., de Souza, I.R., Kun, J.F., Petzl-Erler, M.L., 2006 Diversity of the MBL2 gene in various Brazilian populations and the case of selection at the mannose-binding lectin locus. Hum. Immunol. 67 (9), 722-734

Bouwman, L.H. Roep, B.O. Roos, A. 2006. Mannose-binding lectin: clinical implications for infection, transplantation, and autoimmunity. Hum. Immunol. 67 (4-5), 247-256.

Brazil. Ministry of Health. 2008. National Health Surveillance: progress report: Pernambuco. second ed. Ministry of Health Surveillance - Secretary of Health, Brasília.

Capparelli, R., Iannaccone, M., Palumbo, D., Medaglia, C., Moscariello, E., Russo, A., Iannelli, D., 2009. Role played by human mannose-binding lectin polymorphisms in pulmonary tuberculosis. J. Infect. Dis. 199, 666-672.

Clark-Curtiss, J.E., Haydel, S.E., 2003. Molecular genetics of mycobacterium tuberculosis pathogenesis. Annu. Rev. Microbiol. 57, 517-549.

Cosar, H., Ozkinay, F., Onay, H., Bayram, N., Bakiler, A.R., Anil, M., Can, D., Ozkinay, C., 2008. Low levels of mannose-binding lectin confers protection against tuberculosis in Turkish children. Eur. J. Clin. Microbiol. Infect. Dis. 12, 11651169.

Davies, J., Turner, M., Klein, N., 2001. The role of the collectin system in pulmonary defence. Pediatr. Respir. Rev. 2, 70-75.

Denholm, J.T., McBryde, E.S., Eisen, D.P., 2010. Mannose-binding lectin and susceptibility to tuberculosis: a meta-analysis. Clin. Exp. Immunol. 162, 84-90.

Ducati, R.G., Ruffino-Netto, A., Basso, L.A., Santos, D.S., 2006. The resumption of consumption: a review on tuberculosis. Mem. Inst. Oswaldo Cruz 101, 697-714

El Sahly, H.M. Reich, R.A, Dou, S.J., Musser, J.M., Graviss, E.A, 2004. The effect of mannose binding lectin gene polymorphisms on susceptibility to tuberculosis in different ethnic groups. Scand. J. Infect. Dis. 2, 106-108.

Garcia-Laorden, M.I., Pena, M.J., Caminero, J.A., Garcia-Saavedra, A., CamposHerrero, M.I. Caballero, A., Rodriguez-Gallego, C., 2006. Influence of mannosebinding lectin on HIV infection and tuberculosis in a Western-European population. Mol. Immunol. 14, 2143-2150.

Garred, P., Madsen, H.O., Balslev, U., Hofmann, B., Pedersen, C., Gerstoft, J., Svejgaard, A., 1997. Susceptibility to HIV infection and progression of AIDS in relation to variant alleles of mannose-binding lectin. Lancet 349, 236-240.

Garred, P., Larsen, F., Seyfarth, J., Fujita, R., Madsen, H.O., 2006. Mannose-binding lectin and its genetic variants. Genes Immun. 7, 85-94.

Goldfeld, A.E., Delgado, J.C., Thim, S., Bozon, M.V., Uglialoro, A.M., Turbay, D., Cohen C., Yunis, E.J., 1998. Association of an HLA-DQ allele with clinical tuberculosis JAMA 279, 226-228.

Greenwood, C.M.E., Fujiwara, T.M., Boothroyd, L., Fanning, A., Miller, M., Schurr, E. Morgan, K., 2000. Genetic epidemiology of tuberculosis susceptibility and analysis of linkage to chromosome 2q35 near NRAMP1 in a large Aboriginal Canadian family. Am. J. Hum. Genet. 67, 405-416.

Hijjar, M.A., Ribeiro de Oliveira, M.J.P., Teixeira, G.M., 2001. A Tuberculose no Brazil e no mundo. Boletim de Pneumologia Sanitária. vol. 9 (2), jul/dez - 2001.

Hoal-Van Helden, E.G., Epstein, J., Victor, T.C., Hon, D., Lewis, L.A., Beyers, N., Zurakowski, D., Ezekowitz, A.B., Van Helden, P.D., 1999. Mannose-binding protein $B$ allele confers protection against tuberculous meningitis. Pediatr. Res. 45 (4 Pt. 1), 459-464

Khlat, M., Cazes, M.H., Génin, E., Guiguet, M., 2004. Robustness of case-control studies of genetic factors to population stratification: magnitude of bias and type I error. Cancer Epidemiol. Biomarkers Prev. 13, 1660-1664.

Lee, W.C., Wang, L.Y., 2008. Simple formulas for gauging the potential impacts of population stratification bias. Am. J. Epidemiol. 167, 86-89.

Liu, W., Zhang, F., Xin, Z.T., Zhao, Q.M., Wu, X.M., Zhang, P.H., de Vlas, S., Richardus J.H., Habbema, J.D.F., Yang, H., Cao, W.C., 2010. Sequence variations in the MBL gene and their relationship to pulmonary tuberculosis in the Chinese Han population. Int. J. Tuberc. Lung Dis. 10, 1098-1103.

Madsen, H.O., Garred, P., Kurtzhals, J.A., Lamm, L.U., Ryder, L.P., Thiel, S., Svejgaard, A., 1994. A new frequent allele is the missing link in the structural polymorphism of the human mannan-binding protein. Immunogenetics 1 37-44.

Miller, E.N., Jamieson, S.E., Joberty, C., Fakiola, M., Hudson, D., Peacock, C.S., Cordell H.J., Shaw, M.A., Lins-Lainson, Z., Shaw, J.J., Ramos, F., Silveira, F., Blackwell, J.M., 2004. Genome-wide scans for leprosy and tuberculosis susceptibility genes in Brazilians. Genes Immun. 5, 63-67.

Morris, G.A., Edwards, D.R., Hill, P.C., Wejse, C., Bisseye, C., Olesen, R., Edwards, T.L. Gilbert, J.R., Myers, J.L., Stryjewski, M.E., Abbate, E., Estevan, R., Hamilton, C.D. Tacconelli, A., Novelli, G., Brunetti, E., Aaby, P., Sodemann, M., Østergaard, L., Adegbola, R., Williams, S.M., Scott, W.K., Sirugo, G., 2011. Interleukin 12B (IL12B) Genetic Variation and Pulmonary Tuberculosis: A Study of Cohorts from the Gambia, Guinea-Bissau, United States and Argentina. PLoS One 6 (2), e16656.

Oliveira, M.M., Silva, J.C.S., Costa, J.F., Amim, L.H., Loredo, C.C.S., Melo, H., Queiroz, L.F., Lapa e Silva, J.R., Kritski, A.L., Santos, A.R., 2004. Single nucleotide polymorphisms (SNPs) of the TNF- $\alpha(-238 /-308)$ gene among TB and nom TB patients: susceptibility markers of TB occurrence? J. Bras. Pneumol. 4, 371377. 
Pritchard, J.K., Donnelly, P., 2001. Case-control studies of association in structured or admixed populations. Theor. Popul. Biol. 60, 227-237.

R Development Core Team, 2012. R: A language and environment for statistical computing, R Foundation for Statistical Computing, Vienna, Austria. ISB N3900051-07-0.

Remus, N., El Baghdadi, J., Fieschi, C., Feinberg, J., Quintin, T., Chentoufi, M., Schurr E., Benslimane, A., Casanova, J.L., Abel, L., 2004. Association of IL12RB1 polymorphisms with pulmonary tuberculosis in adults in Morocco. J. Infect. Dis. 190 (3), 580-587.

Selvaraj, P., Jawahar, M.S., Rajeswari, D.N., Alagarasu, K., Vidyarani, M., Narayanan P.R., 2006. Role of mannose binding lectin gene variants on its protein levels and macrophage phagocytosis with live Mycobacterium tuberculosis in pulmonary tuberculosis. Immunol. Med. Microbiol. 46, 433-437.

Singh, S.P., Mehra, N.K., Dingley, H.B., Pande, J.N., Vaidya, M.C., 1983. Human leukocyte antigen (HLA)-linked control of susceptibility to pulmonary tuberculosis and association with HLA-DR types. J. Infect. Dis. 148, 676-681.

Søborg, C., Madsen, H., Andersen, Å., Lillebaek, T., Kok-Jensen, A., Garred, P., 2003. Mannose-binding lectin polymorphisms in clinical tuberculosis. J. Infect. Dis. $188,777-782$

Solğun, H.A., Taştemir, D., Aksaray, N., Inan, I., Demirhan, O., 2011. Polymorphisms in NRAMP1 and MBL2 genes and their relations with tuberculosis in Turkish children. Tuberk. Toraks 1, 48-53.
Steffensen, R., Thiel, S., Varming, K., Jersild, C., Jensenius, J.C., 2000. Detection of structural gene mutations and promoter polymorphisms in the mannanbinding lectin (MBL) gene by polymerase chain reaction with sequencespecific primers. J. Immunol. Methods 241, 33-42.

Thye, T., Niemann, S., Walter, K. Homolka, S, Intemann, C.D., Chinbuah, M.A. Enimil, A., Gyapong, J., Osei, I., Owusu-Dabo, E., Rüsch-Gerdes, S., Horstmann, R.D., Ehlers, S., Meyer, C.G., 2011. Variant G57E of mannose binding lectin associated with protection against tuberculosis caused by mycobacterium Africanum but not by M. tuberculosis. PLoS One 6 (6), e20908.

Wacholder, S., Rothman, N., Caporaso, N., 2000. Population stratification in epidemiologic studies of common genetic variants and cancer: quantification of bias. J. Natl. Cancer Inst. 92 (14), 1151-1158.

Wallis, R., 2003. Structural basis for mannose-binding protein functions in innateimmunity. In: Wong, Y.C., Arsequell, G. (Eds.), Immunobiology of Carbohydrates. Landes Bioscience, Texas, pp. 34-45.

WHO - World Health Organization. Global Tuberculosis Control, 2011. <http:// www.who.int/tb/publications/global_report/2011/gtbr11_full.pdf>.

Wilkinson, R.J., Llewelyn, M., Toossi, Z., Patel, P., Pasvol, G., Lalvani, A., Wright, D., Latif, M., Davidson, R.N., 2000. Influence of vitamin D deficiency and vitamin D receptor polymorphisms on susceptibility to tuberculosis amongst Gujarati Asians in west London: a case-control study. Lancet 355, 618-621. 